\title{
PENGARUH MEDIA PEMBELAJARAN TERHADAP MOTIVASI DAN HASIL BELAJAR SISWA PADA PEMBELAJARAN KOSAKATA BAHASA INGGRIS
}

\author{
Dewi Ayu Nur Wulandari \\ Program Studi Komputer Akuntansi, AMIK BSI Karawang \\ Jl. Ahmad Yani No. 98, Karawang \\ dewi.dan@bsi.ac.id
}

\begin{abstract}
This study aims to determine the effect of the use of multimedia learning English vocabulary on learning outcomes and student motivation. The method used in this study is a quasi-experimental method with a non-equivalent control group design. The non-equivalent control group design was chosen because the study subjects were not taken at random from the population but were taken from all subjects that are formed naturally .. Data learning results obtained by conducting a test in the form of essays. Questions used during the pretest and posttest is exactly the same problem. In this study, researchers created two groups that get the treatment and control groups. The treatment group was given treatment classes will be learning English vocabulary-based multimedia. While the control group is the class that will be used as a comparison with getting treatment vocabulary learning using media blackboard and textbooks. In the early stages of testing conducted Kolmogorov-Smirnov test and homogeneity test followed by two groups using the Levene test. Based on the results of Kolmogorov-Smirnov test data obtained significance level probability of above 0.05 ( $p>0.05$ ), namely value pretest experimental group 0759, Value pretest control group 0851, Value posttest experimental group 0945, Value posttest control group 0925, Value Motivation experimental group 0688, Value Motivation 0902 control group. Based on the results of data analysis showed that the levene test sig. (P-value) of data pre-test data as well as data posttes motivation of both groups was> 0.05, thus the two data homogeneous. It can be concluded an increase in the average value of significant before and after using multimedia learning. This shows that the use of multimedia learning positive effects.
\end{abstract}

Keywords: Multimedia learning English vocabulary, Influence Multimedia

\section{PENDAHULUAN}

Pelajaran Bahasa Inggris di sekolah dasar merupakan kurikulum muatan lokal sesuai dengan Kebijakan Depdikbud RI No. 0487/4/1992, Bab VIII, menyatakan bahwa sekolah dasar dapat menambah mata pelajaran dalam kurikulumnya, asalkan pelajaran itu tidak bertentangan dengan tujuan pendidikan nasional. Kemudian, kebijakan ini disusul oleh SK Menteri Pendidikan dan Kebudayaan No. 060/U/1993 tanggal 25 Februari 1993 tentang dimungkinkannya program Bahasa Inggris di sebagai mata pelajaran muatan lokal SD, dan dapat dimulai pada kelas 4 SD. Muatan lokal merupakan kegiatan kurikuler untuk mengembangkan kompetensi yang disesuaikan dengan daerah masing-masing. Kurikulum muatan lokal tidak tidak disusun oleh Pusat Kurikulum Depdiknas tetapi dikembangkan di tingkat provinsi yang kemudian disesuaikan dengan kebutuhan masing-masing daerah.

Dalam proses pembelajaran bahasa inggris di sekolah, terkadang siswa mengalami kejenuhan. Hal ini di karenakan proses belajar mengajar yang dilakukan masih hanya menggunakan media buku dan papan tulis. Hal ini mengakibatkan proses pembelajaran kurang menarik dan kurang mudah dipahami. Oleh karena itu diperlukan media pembelajaran yang dapat menarik minat belajar siswa.

Dengan semakin berkembangnya ilmu pengetahuan dan teknologi, semakin banyak masyarakat yang mulai menyadari akan pentingnya media pembelajaran berbasis multimedia. Pembelajaran berbasis media juga dapat membantu siswa dalam belajar dan membantu proses belajar lebih menyenangkan. Pemilihan media pembelajaran yang tepat merupakan salah satu faktor yang dapat mempengaruhi pencapaian dari tujuan pembelajaran sesuai dengan kompetensi yang diharapkan.

Penggunaan media pembelajaran berbasis komputer merupakan salah satu bentuk dari pemanfaatan teknologi yang dapat digunakan oleh pendidik karena dapat mengurangi batasan 
ruang dan waktu, sehingga proses pembelajaran tetap dapat berjalan walaupun tidak didampingi oleh guru.

Salah satu faktor yang menyebabkan belum meningkatnya kualitas pembelajaran adalah belum dimanfaatkannya sumber belajar atau media dengan maksimal. Terbatasnya pemanfaatan TIK dalam pembelajaran di kelas diduga merupakan salah satu sebab lemahnya mutu pendidikan pada umumnya (Zinnurain dan Gafur, 2015 : 158).

Menurut Arda dkk (2015:1) Media merupakan salah satu faktor yang mendukung keberhasilan proses pembelajaran di sekolah karena dapat membantu proses penyampaian informasi dari guru kepada siswa ataupun sebaliknya. Penggunaan media secara kreatif dapat memperlancar dan meningkatkan efesiensi pembelajaran sehingga tujuan pembelajaran dapat tercapai.

Pada penelitian sebelumnya penulis sudah melakukan penelitian tetapi dengan menggunakan metode one group pretestposttest design. Pada penelitian kali ini penulis menggunakan metode quasi eksperimen subjek penelitian tidak diambil secara acak dari populasi tetapi diambil dari seluruh subjek yang terbentuk secara alami. Tujuan dari penelitian ini adalah untuk mengetahui pengaruh penggunaan multimedia pembelajaran terhadap hasil belajar dan motivasi belajar siswa.

\section{KAJIAN LITERATUR}

A. Multimedia Pembelajaran

Menurut (Wahono, 2008), ada dua jenis multimedia pembelajaran jika dikategorikan menurut kegunaannya, yaitu :

\section{Multimedia Presentasi Pembelajaran}

Merupakan alat bantu guru dalam penyampaian proses pembelajaran di kelas tetapi tidak menggantikan guru secara keseluruhan. Berupa materi yang di sajikan (explicit knowledge) dan dapat di kombinasikan dengan multimedia linier berupa film dan video untuk memperkuat pemahaman siswa.

\section{Multimedia Pembelajaran Mandiri}

Merupakan alat pembelajaran berupa Software yang dapat dimanfaatkan oleh siswa secara mandiri tanpa bantuan guru. Multimedia pembelajaran mandiri ini dapat memadukan antara explicit knowledge (pengetahuan tertulis yang ada di buku, artikel, dsb) dan tacit knowledge (know how, rule of thumb, pengalaman guru). Karena perannya untuk menggantikan guru, harus ada fitur latihan, ujian (test) dan tahapan pemecahan masalah.

\section{B. Bahasa Inggris Untuk Siswa Sekolah Dasar \\ Menurut Cameron dalam Zulkifli} (2014:181), ada 4 indikator yang memiliki pengaruh besar dalam penguasaan berbahasa inggris untuk usia dini (English for Young Learner), yaitu :

1. Pengucapan (Pronunciation)

Bagaimana kata diucapkan adalah salah satu aspek yang memiliki pengaruh besar penguasaan berbahasa.

2. Ejaan (Spelling)

Siswa juga perlu mengetahui huruf dan suku kata yang membentuk kata, itu disebut ejaan.

3. Perubahan Struktur Bahasa (Grammatical Change)

Adalah penting mengetahui perubahan struktur bahasa pada kata, dan dengan belajar perubahan kata siswa dapat memahami struktur tata bahasa. Hal ini menunjukkan bahwa jika kita memberikan prioritas tinggi untuk belajar perubahan struktur kata, kita dapat memahami dengan baik tata bahasa

4. Makna (Meaning)

Nation dalam Cameron (2001: 85) berpendapat "cara untuk menjelaskan makna kata baru pelajar usia dini, yaitu dengan menggunakan objek, tokoh, gesture, tindakan, foto, gambar atau diagram pada papan, gambar dari buku cerita." Menemukan makna untuk kata bahasa asing yang baru adalah baik untuk proses kerja otak anak, dengan cara berfikir dan mengingat kata baru.

\section{Alasan Pengajaran Bahasa Inggris di Sekolah Dasar}

Menurut Brumfit dalam Zulkifli (2014 : 180) mengatakan bahwa ada sejumlah alasan pengajaran Bahasa Inggris di tingkat SD:

1. Memperkenalkan kepada anak-anak sejak dini dalam memahami budaya asing sehingga tumbuh sikap toleransi dan simpatik.

2. Alat berkomunikasi dalam memahami konsep-konsep baru

3. Waktu belajar yang maksimal, tidak membutuhkan banyak waktu untuk dapat menguasainya

4. Dapat digunakan sebagai media pembelajaran

Di tambahkan pula oleh brumfit, alasan pengajaran bahasa Inggris di tingkat dasar adalah belajar budaya lain dan untuk mendapatkan waktu belajar yang 
maksimal. Ini berarti bahwa waktu terbaik untuk belajar bahasa adalah usia dini. Sekolah Dasar adalah tempat terbaik untuk memulai mengajar dan belajar bahasa Inggris.

\section{Instrumen Penelitian}

Menurut Sugiyono (2011:92) "Skala Pengukuran merupakan kesepakatan yang digunakan sebagai acuan untuk menentukan panjang pendeknya interval yang ada dalam alat ukur, sehingga alat ukur tersebut bila digunakan dalam pengukuran akan menghasilkan data kuantitatif.

Menurut Sugiyono (2011:93) Berbagai skala sikap yang dapat digunakan untuk penelitian administrasi, pendidikan dan sosial antara lain adalah:

1. Skala Likert

2. Skala Guttman

3. Rating Scale

4. Semantic Deferential

Dalam pembuatan laporan skripsi ini, penulis meggunakan skala pengukuran dalam menyusun kuesioner dengan menggunakan Skala Likert.

Menurut Sugiyono (2011:93) "Skala Likert digunakan untuk mengukur sikap, pendapat, dan presepsi seseorang atau sekelompok orang tentang fenomena sosial. Dalam penelitian, fenemona sosial ini telah ditetapkan secara spesifik oleh peneliti, yang selanjutnya disebut sebagai variabel penelitian".

Dengan skala likert, maka variabel yang akan diukur dijabarkan menjadi indikator variabel. Kemudian indikator tersebut dijadikan titik tolak untuk menyusun item-item instrumen yang dapat berupa pertanyaan atau pertanyaan.

Jawaban setiap item instrumen yang menggunakan skala likert mempunyai gradasi dari sangat positif sampai sangat negatif, yang dapat berupa kata-kata lain:
a. Sangat Setuju
b. Setuju
c. Ragu-ragu
d. Kadang-kadang
e. Sangat Tidak setuju

\section{E. Subyek Penelitian}

Subyek Penelitian menurut Arikunto (2006:145) subyek yang dituju oleh peneliti untuk diteliti.

\section{F. Populasi}

Menurut Sugiyono (2011:80) menjelaskan bahwa populasi adalah wilayah generalisasi yang terdiri atas obyek atau subyek yang mempunyai kualitas dan karakteristik tertentu yang ditetapkan oleh penelitian untuk dipelajari dan kemudian ditarik kesimpulannya, Jadi populasi bukan hanya orang, tetapi juga obyek dan benda-benda alam yang lain. Populasi juga bukan sekedar Jumlah yang ada pada obyekatau subyek yang dipelajari, tetapi meliputi seluruh karakteristik atau sifat yang dimiliki oleh subyek atau obyek itu.

\section{METODE PENELITIAN}

Metode penelitian yang digunakan dalam penelitian ini adalah metode quasi eksperimen dengan non-equivalent control group design. Jenis non-equivalent control group design di pilih karena subjek penelitian tidak diambil secara acak dari populasi tetapi diambil dari seluruh subjek yang terbentuk secara alami.

Pada penelitian ini peneliti membuat 2 kelompok yaitu kelompok yang mendapatkan perlakuan dan kelompok kontrol. Kelompok perlakuan selanjutnya disebut dengan kelas eksperimen adalah kelas yang akan diberikan treatment berupa pembelajaran kosakata bahasa inggris berbasis multimedia. Sedangkan kelompok kontrol adalah kelas yang akan dijadikan sebagai pembanding dengan mendapatkan perlakuan pembelajaran kosakata menggunakan media papan tulis dan buku ajar.

Beberapa langkah pembelajaran yang dilakukan dalam penelitian ini adalah sebagai berikut :

Pada kelompok yang mendapatkan perlakuan, pembelajaran kosakata bahasa inggris dilakukan dengan menggunakan bantuan multimedia pembelajaran kosakata bahasa inggris yang telah disiapkan sebelumnya. Sebelum pembelajaran di mulai, peneliti terlebih dahulu melakukan pretest dengan menggunakan soal essay. Pada pertemun terakhir, siswa pada kelas perlakuan akan diberikan test akhir posttest menggunakan soal yang sama persis ketika pretest.

Pada kelompok kontrol, pembelajaran kosakata bahasa inggris tidak dilakukan dengan bantuan multimedia pembelajaran, tetapi menggunakan metode konvensional, yaitu dengan metode ceramah dan bantuan papan tulis. Sama seperti pada kelompok eksperimen, pada kelompok kontrol sebelum dilakukan pembelajaran, terlebih dahulu peneliti memberikan soal pretest. Pada pertemuan akhir pun peneliti memberikan soal posttest. Soal pretest dan posttest yang diberikan pada kelompok kontrol merupakan soal yang sama yang juga diberikan pada kelompok perlakuan.

Instrumen yang digunakan dalam penelitian ini adalah berbentuk tes berupa soal 
pretest dan posttest. Soal yang digunakan pada saat pretest dan posttest adalah soal yang sama persis. Hal ini dikarenakan untuk mengetahui adanya perbedaan ataupun peningkatan hasil belajar siswa sebelum dan sesudah diberikan perlakuan yang berbeda diantara kedua kelas tersebut.

\section{PEMBAHASAN}

A. Data Hasil Pembelajaran

Berikut ini akan dipaparkan data hasil pembelajaran dari 2 kelompok.

\section{Data Pretest kelompok eksperimen dan kelompok kontrol}

Pretest merupakan test yang dilakukan diawal sebelum pelaksanaan pembelajaran dimulai. Tujuan dari pretest ini adalah untuk mengetahui kemampuan awal dan tingkat pemahaman awal kedua kelompok baik kelompok eksperimen maupun kelompok kontrol dalam hal pemahaman kosakata bahasa inggris.

Berdasarkan hasil analisis deskriptif di peroleh hasil data sebagai berikut: pada kelompok eksperimen diperoleh mean $=62,5806$; median $=45$; simpangan baku $=11,60969 ;$ varian $=134,785$; skor terendah $=40$; skor tertinggi $=85$; Sedangkan untuk kelompok kontrol diperoleh hasil data sebagai berikut : mean $=62,7419 ;$ median $=40 ;$ simpangan baku $=12,16818 ;$ varian $=148,065 ;$ skor terendah $=40$; skor tertinggi $=80$;

Tabel 1. Data Pretest Kelompok Eksperimen dan Kelompok Kontrol

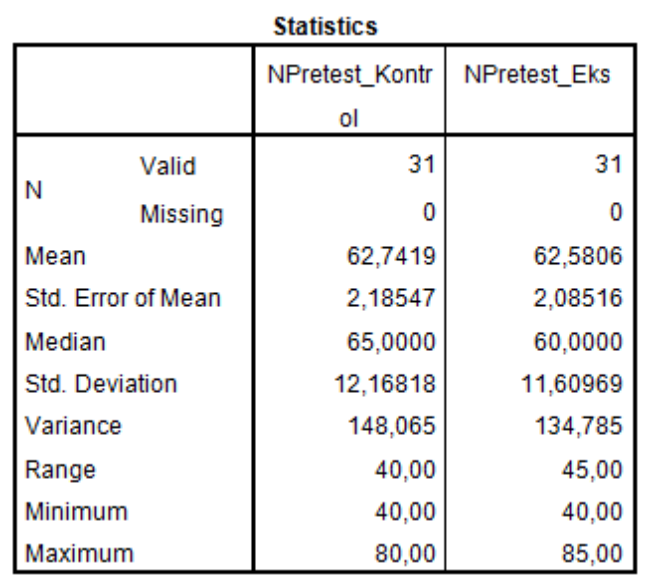

Sumber: Hasil Penelitian (2016)

Berdasarkan hasil analisis deskriptif tersebut di atas, menunjukan bahwa rerata skor hasil belajar dari kedua kelompok baik kelompok eksperimen dan kelompok kontrol tidak berbeda jauh, yakni rerata skor kelompok eksperimen adalah 62,5806, sedangkan rerata skor kelompok kontrol adalah 62,7419. Berdasarkan data tersebut di atas maka dapat disimpulkan bahwa hasil pretest dari kedua kelompok tidak terdapat perbedaan yang signifikan.

\section{Data Posttest Kelompok Eksperimen dan kelompok kontrol}

Posttest yang dilakukan pada kelompok eksperimen dilakukan dengan tujuan untuk melihat perubahan hasil belajar pada siswa setelah mendapat pengajaran dengan menggunakan animasi pembelajaran kosakata bahasa inggris. Instrumen dari posttest pada kelas eksperimen menggunakan soal yang sama pada saat posttest.

Berdasarkan hasil analisis deskriptif di peroleh hasil data sebagai berikut: pada kelompok eksperimen diperoleh mean $=75,1613$; median $=75$; simpangan baku $=8,41466$; varian $=70,806$; skor terendah $=60$; skor tertinggi $=90$;

Tabel 2. Data Posttest Kelompok Eksperimen Statistics

\begin{tabular}{|c|c|c|}
\hline \multicolumn{3}{|c|}{ NPosttest_Eks } \\
\hline \multirow{2}{*}{$\mathrm{N}$} & Valid & 31 \\
\hline & Missing & 0 \\
\hline \multicolumn{2}{|c|}{ Mean } & 75,1613 \\
\hline \multicolumn{2}{|c|}{ Std. Error of Mean } & 1,51132 \\
\hline \multicolumn{2}{|c|}{ Median } & 75,0000 \\
\hline \multicolumn{2}{|c|}{ Std. Deviation } & 8,41466 \\
\hline \multicolumn{2}{|c|}{ Variance } & 70,806 \\
\hline \multicolumn{2}{|c|}{ Range } & 30,00 \\
\hline \multicolumn{2}{|c|}{ Minimum } & 60,00 \\
\hline \multicolumn{2}{|c|}{ Maximum } & 90,00 \\
\hline
\end{tabular}

Sumber: Hasil Penelitian (2016)

\section{Data Posttest Kelompok Kontrol}

Posttest yang dilakukan pada kelompok kontrol dilakukan dengan tujuan untuk melihat perubahan hasil belajar pada siswa setelah mendapat pengajaran dengan menggunakan media papan tulis dan buku teks. Instrumen dari posttest pada kelas kontrol juga menggunakan soal yang sama pada saat posttest.

Berdasarkan hasil analisis deskriptif di peroleh hasil data sebagai berikut: pada kelompok kontrol diperoleh mean $=63,8710$; median $=$ 60 ; simpangan baku $=10,30450$; varian $=$ 106,183 ; skor terendah $=50$; skor tertinggi $=$ 85 ; 
Tabel 3. Data Posttest Kelompok Kontrol Statistics

NPosttest_Kontrol
\begin{tabular}{|l|r|}
\hline N $\quad$ Valid & 31 \\
Mean & Missing \\
Std. Error of Mean & 0 \\
Median & 1,85074 \\
Std. Deviation & 60,0000 \\
Variance & 10,30450 \\
Range & 106,183 \\
Minimum & 35,00 \\
Maximum & 50,00 \\
\end{tabular}

Sumber: Hasil Penelitian (2016)

Tabel 4. Hasil Posttest Kelompok Eksperimen dan Kelompok Kontrol

\begin{tabular}{|c|c|c|}
\hline \multicolumn{3}{|c|}{ Statistics } \\
\hline & NPosttest_Eks & $\begin{array}{c}\text { NPosttest_Kont } \\
\text { rol }\end{array}$ \\
\hline Valid & 31 & 31 \\
\hline Missing & 0 & 0 \\
\hline Mean & 75,1613 & 63,8710 \\
\hline Std. Error of Mean & 1,51132 & 1,85074 \\
\hline Median & 75,0000 & 60,0000 \\
\hline Std. Deviation & 8,41466 & 10,30450 \\
\hline Variance & 70,806 & 106,183 \\
\hline Range & 30,00 & 35,00 \\
\hline Minimum & 60,00 & 50,00 \\
\hline Maximum & 90,00 & 85,00 \\
\hline
\end{tabular}

Sumber: Hasil Penelitian (2016)

Berdasarkan hasil data yang diperoleh dari kedua kelompok, menunjukkan bahwa rata-rata nilai yang diperoleh dari kedua kelompok berbeda secara signifikan, yaitu untuk kelompok eksperiment rata-rata nilai $($ mean $)=$ 75,1613 dan rata-rata nilai untuk kelompok kontrol adalah 63,8710 .

\section{B. Data Motivasi Pembelajaran}

Data motivasi pembelajaran dimaksudkan untuk melihat perbedaan motivasi belajar para siswa jika proses pembelajaran dilakukan dengan menggunakan animasi pembelajaran dan pembelajaran dilakukan hanya dengan media buku dan papan tulis.

Data motivasi pembelajaran di ambil bersamaan dengan kegiatan posttest yaitu sebelum kegiatan pembeljaran dimulai. Data diperoleh melalui hasil angket yang disebar kepada para siswa.

\section{Data Motivasi Belajar Kelompok Eksperimen}

Berdasarkan hasil analisis deskriptif di peroleh hasil data sebagai berikut: pada kelompok eksperimen diperoleh mean $=23,619$; median $=24$; simpangan baku $=2,04414$; varian $=4,178$; skor terendah $=20$; skor tertinggi $=28$;

Tabel 6. Hasil Motivasi Belajar Kelompok Eksperimen

Statistics

Motivasi_Eks
\begin{tabular}{|l|r|}
\hline N $\quad$ Valid & 31 \\
& Missing \\
Mean & 0 \\
Median & 23,6129 \\
Std. Deviation & 24,0000 \\
Variance & 2,04414 \\
Range & 4,178 \\
Minimum & 8,00 \\
Maximum & 20,00 \\
Sum & 28,00 \\
\hline
\end{tabular}

Sumber: Hasil Penelitian (2016)

\section{Data Motivasi Belajar Kelompok Kelompok}

Berdasarkan hasil analisis deskriptif di peroleh hasil data sebagai berikut: pada kelompok eksperimen diperoleh mean $=21,5806$; median $=21$; simpangan baku $=2,82576$; varian $=7,985$; skor terendah $=16$; skor tertinggi $=27$;

Tabel 7. Hasil Motivasi Belajar Kelompok Kontrol

Statistics

Motivasi_Kontrol

\begin{tabular}{|l|r|}
\hline N $\quad$ Valid & 31 \\
Mean & 0 \\
Median & 21,5806 \\
Std. Deviation & 21,0000 \\
Variance & 2,82576 \\
Range & 7,985 \\
Minimum & 11,00 \\
Maximum & 16,00 \\
Sum & 27,00 \\
\hline
\end{tabular}

Sumber: Hasil Penelitian (2016) 
Berdasarkan hasil analisa deskriptif yang telah dilakukan, diketahui bahwa terdapat perbedaan rata-rata nilai motivasi kelompok eksperimen dan kelompok kontrol. Nilai rata-rata (mean) kelompok eksperimen adalah sebesar 23,619 yang lebih besar dari mean kelompok kontrol sebesar 21,5806.

\section{Hasil Pengujian}

Hasil uji-t dimaksudkan untuk mengetahui dan membandingkan perbedaan skor posttest dan skor motivasi belajar yang diperoleh kelompok eksperimen dan kelompok kontrol. Pada tahap awal pengujian dilakukan uji KolmogorovSmirnov dan dilanjutkan dengan pengujian homogenitas data kelompok ekperimen dan kelompok kontrol dengan menggunakan uji Levene

Tabel 8. Hasil Uji Kolmonogrov-Smirnov

\begin{tabular}{|c|c|c|c|c|c|c|c|}
\hline \multicolumn{8}{|c|}{ One-Sample Kolmogorov-Smimov Test } \\
\hline & & $\begin{array}{c}\text { NPretest_E } \\
\text { ks }\end{array}$ & $\begin{array}{c}\text { NPretest_K } \\
\text { ontrol }\end{array}$ & $\begin{array}{c}\text { NPostest_ } \\
\text { Eks }\end{array}$ & $\begin{array}{c}\text { NPostest_ } \\
\text { Kontol } \\
\end{array}$ & $\begin{array}{c}\text { Mofvasi_E } \\
\mathrm{ks}\end{array}$ & $\begin{array}{c}\text { Motivasi_Ko } \\
\text { ntol }\end{array}$ \\
\hline \multirow[t]{2}{*}{$\mathrm{N}$} & & 31 & 31 & 31 & 31 & 31 & 31 \\
\hline & Mean & 62,5808 & 62,7419 & 75,1613 & 63,8710 & 23,6129 & 21,5800 \\
\hline Normal Parameters ${ }^{25}$ & $\begin{array}{l}\text { Stt. } \\
\text { Deviation }\end{array}$ & 11,60969 & 12,16818 & 8,41468 & 10,30450 & 2,04414 & 2,82576 \\
\hline \multirow{2}{*}{ Most Extreme } & Absolute &, 138 &, 153 &, 170 &, 188 & .123 & 162 \\
\hline & Posifie & .138 & .098 &, 121 & .188 & .108 & 162 \\
\hline Differences & Negative &,- 122 & -153 &,- 170 &,- 128 &,- 123 &,- 084 \\
\hline \multicolumn{2}{|l|}{ KolmogorovSSmirnov Z } &, 759 & 851 & 945 & 925 & .688 & .902 \\
\hline \multicolumn{2}{|l|}{ Asymp. Sig. (2-tailed) } & .812 & .484 & 333 & 360 &, 732 & 390 \\
\hline
\end{tabular}

Sumber: Hasil Penelitian (2016)

Berdasarkan hasil uji normalitas data dengan menggunakan Kolmogorov-Smirnov didapat data sebagai berikut : Output Normalitas Data dengan uji Kolmogrov-Smirnov seperti yang terlihat pada tabel 1 didapat tingkat signifikasi atau nilai probabilitasnya diatas 0.05 ( $>>0.05)$ yaitu Nilai Pretest kelompok eksperimen 0.759, Nilai Pretest kelompok kontrol 0.851, Nilai Posttest kelompok eksperimen 0.945, Nilai Posttest kelompok kontrol 0.925, Nilai Motivasi kelompok eksperimen 0.688, Nilai Motivasi kelompok kontrol 0.902. Dari hasil tersebut maka dapat dikatakan distribusi kedua sampel adalah normal.

Berikutnya yang akan dilakukan adalah uji homogenitas kedua kelompok dengan menggunakan uji Lavene. Sebelum diuji menggunakan SPSS data nilai pretest, posttest dan motivasi digabung menjadi satu kolom dan dilakukan uji one-way annova. Berikut ini adalah hasil uji homogenitas lavene dengan menggunakan SPSS :

Tabel 9. Tes Homogenitas dengan Lavene

Test of Homogeneity of Variances

\begin{tabular}{|l|r|r|r|r|}
\hline & Levene Statistic & df1 & df2 & \multicolumn{1}{c|}{ Sig. } \\
\hline Pretest &, 027 & 1 & 60 &, 871 \\
Posttest & 1,213 & 1 & 60 &, 275 \\
Motivasi & 3,188 & 1 & 60 &, 079 \\
\hline
\end{tabular}

Sumber: Hasil Penelitian (2016) 
Berdasarkan data hasil analisis uji lavene pada tabel di atas menunjukkan bahwa nilai sig. (pvalue) data pretes 0,871 , data posttes 0,275 serta data motivasi 0,079 . Ini menunjukkan

\section{PENUTUP}

Hasil penelitian ini menunjukkan bahwa berdasarkan hasil analisis deskriptif di peroleh hasil data sevagai berikut :

1. Berdasarkan hasil analisis deskriptif di peroleh hasil data sebagai berikut: pada kelompok eksperimen diperoleh mean = 75,1613; median $=75$; simpangan baku $=$ 8,41466 ; varian $=70,806$; skor terendah $=60$; skor tertinggi $=90$;

2. Berdasarkan hasil analisis deskriptif di peroleh hasil data sebagai berikut: pada kelompok kontrol diperoleh mean = 63,8710; median $=60$; simpangan baku $=$ 10,30450 ; varian $=106,183$; skor terendah $=50$; skor tertinggi $=85$;

Hal ini menunjukkan bahwa hasil belajar siswa yang mendapatkan pengajaran dengan bantuan media animasi pembelajaran lebih tinggi dibandingkan dengan yang hanya menggunakan media buku teks dan bantuan papan tulis.

\section{DAFTAR PUSTAKA}

Arda dkk. 2015. Pengembangan Media Pembelajaran Interaktif Berbasis komputer bahwa data hasil uji lavene kedua kelompok adalah > 0,05, dengan demikian kedua data dapat dikatakan homgen.

Untuk Siswa Smp Kelas VIII. e-Jurnal Mitra Sains, Volume 3 Nomor 1, Januari 2015. ISSN: 2302-2027.

http://jurnal.untad.ac.id/jurnal/index.php/Mitra Sains/article/viewFile/4156/3092

Arikunto. 2013. Proses Penelitian Suatu Pendekatan Praktik. Jakarta: RinekaCipta

Sugiyono. 2011. Metode Penelitian Kuantitatif Kualitatif dan R\&D. Bandung: Alfabeta.

Wahono, Romi Satrio. 2008. Langkah Mudah Membuat Multimedia Pembelajaran. http://romisatriawahono.net/2008/03/03/7-

langkah-mudah-membuat-multimediapembelajaran/. Diakses 10 April 2016.

Zulkifli, Nur Aisyah. 2014. Meningkatkan Kemampuan Bahasa Inggris Siswa Dengan Menggunakan Running Dictation Melalui Materi Agama Di Sd It Al-Fittiyah Pekanbaru. Jurnal Penelitian sosial keagamaan, Vol.17, No.2 Juli-Desember 2014. Hal 175-197.

Zinnurain dan Abdul Gafur. 2015. Jurnal Inovasi Teknologi Pendidikan. Volume 2 , No 2, Oktober 2015. Hal 157-168. 